\title{
Panels and faces: segmented metaphors and reconstituted time in Art Spiegelman's Maus
}

\author{
Liam Kruger
}

\section{Abstract}

An examination of the specifically graphic-novelistic strategies employed in Art Spiegelman's graphic memoir, Maus, in leading the reader into a punctuated experience of time and memory, and in forcing complicity with the novel's problematic animal-as-ethnicity metaphor, in a wider attempt at putting together the critical vocabulary for discussing comic books as simultaneously textual and pictorial 'texts'.

Keywords: graphic novels, history, Maus, memory, Spiegelman, time structure, trauma

...the picture-story, which critics disregard and scholars scarcely notice, has had great influence at all times, perhaps even more than written literature. Rudolphe Töpffer, Essay on Physiognomy (1845)

If there are three things that can be expected of any comic strip, comic book or graphic novel, then these are words, faces and panels. The genre is a diverse one, and it does not seem useful to attempt to generate a hard-and-fast rule by which to define it, but these three aspects, in general, can be depended upon as indicative features. Scott McCloud's (2003: 9) seminal Understanding comics does offer one such definition for comics, although using the broadest terms possible: 'Juxtaposed pictorial and other images in deliberate sequence, intended to convey information and/or to produce an aesthetic response in the viewer.'

Liam Kruger is a Master's candidate at the University of Cape Town. liamwkruger@gmail.com

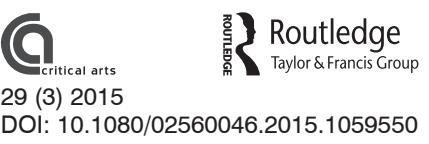

ISSN 0256-0046/Online 1992-6049 pp.357-366

DOI: $10.1080 / 02560046.2015 .1059550$

(c) Critical Arts Projects \& Unisa Press 


\section{Liam Kruger}

McCloud omits the perhaps obvious point that these sequential images usually represent people, or at least individual figures with whom the reader is expected to identify - as indicated, generally, by giving these people or figures faces.

Art Spiegelman's Maus is, to date, the exemplary case for demonstrating the ways in which the presence of faces and panels can generate narrative effects not available to non-pictorial novels. The two-volume graphic memoir depicts Spiegelman's father's experience of the First World War, Weimar Germany and Auschwitz, interspersed by scenes in a contemporary New York, where an 'Artie' interviews his father for a graphic memoir he's working on.

The abiding visual metaphor in Maus is the depiction of Jews - midcentury German and contemporary American - as anthropomorphic mice, drawn in a simple, iconic style, having more in common with Mickey Mouse than genuine mice, and thus easy vessels for readerly projection. A similarly iconic - rather than realistic, to use McCloud's terminology - visual diction is used in Marjane Satrapi's Persepolis, a graphic memoir about the author's childhood in Iran during the Islamic revolution; a clean, occasionally cartoonish style is employed to universalise the particular difficulties of the memoir's cast. An inverse effect can be observed in Harvey Pekar's American splendour. The series is largely illustrated by R. Crumb, who draws far more detailed, if caricatured, individuals than either Satrapi or Spiegelman; this offsets readerly identification even as Pekar's depiction of his urban angst ought to be familiar. Spiegelman's use of a deeply iconic - rather than realistic - style visually primes readers to project themselves onto the 'mouse' figures, even as he prevents this by having the figures represent an ethnically and historically discrete social demographic; his depiction of that ethnic and historical demographic in the comic book form, on the other hand, implicitly communicates the abiding persistence of the past.

We look first to faces, and what they project. In earlier drafts of Maus, Spiegelman toyed with more realistic representations of mice before settling for the simpler style he would eventually adopt. Spiegelman (1994) is explicit as to why this style was chosen, noting 'the mouse heads are masks, virtually blank, like Little Orphan Annie's eye-balls, a white screen the reader can project on'.

The shift towards the white screen takes place within the course of the graphic novel, too. In the novel's prologue, a prepubescent Artie Spiegelman and his father, Vladek Spiegelman, are shown with facial fur, eyes and ears prominently visible - details which show up less frequently as the novel progresses. By the end of the first volume, only the vaguely triangular shape of Artie's head distinguishes him from a crude drawing of a human - if intentional, this gradual shift from pointedly cartoonish masks to near-human faces is a counterpart to what Michael Chaney (2011: 130) describes as the role of the animal in comics, namely 'ludic cipher of otherness ... whose appearance almost always accompanies the strategic and parodic 
veiling of the human'. By gradually disassembling his animal metaphor, Spiegelman is by contrast removing the veil - if not the shroud - that initially covers his retelling of the human experience of Auschwitz. For this to work, however, the reader needs to be lured in by Spiegelman's initial, welcomingly cartoonish cast - and so visually we are primed to find in the mice easy vessels for projection and sympathy. Jeanne Ewert (2000: 97), in Reading visual narrative: Art Spiegelman's 'Maus', takes this further:

The masking function of the mouse heads is underscored when Spiegelman shows the mice passing themselves off as Poles by holding pig masks in front of their faces [see Spiegelman 1986: 66, panels 2-6], and, of course, when the artist himself appears wearing a 'maus' mask [see Spiegelman 1991: 32, panels 2-6]. Spiegelman's stylistic choices, then, move towards a universality of character.

This universality is mitigated to some extent in the novel's first volume by the fact that Spiegelman uses the animal metaphor to describe a subset of people imbricated in a specific cultural and historical situation. Presumably this is why the diction Spiegelman attributes to the German Jews is a mixture of Yiddish and English, to allow the specificity of the text, and occasional use of the Star of David (which occupies an odd space between text and image), to give the lie to the universalising visual metaphor. This is faintly problematic; while the mice, whom Spiegelman associates with German Jews in Volume I, resemble mice less and less as the novel progresses, the cats and pigs - who represent non-Jewish Germans and Poles - that make up the bulk of the rest of the novel do not at any point become more iconic. While the mice lose their whiskers, the German cats never lose, or indeed change, their stripes. Spiegelman's selective use of the iconic visual style therefore actively prevents the reader from sympathising with any demographic other than the Polish and German Jews. This begins to fall away, however, as the depictions of the Jews in Auschwitz grow increasingly crude - exacerbated by the no less iconic but far cleaner panels showing Artie in conversation with Vladek in the second volume's present, which tends to be interposed between Auschwitz sequences. As the drawings of Auschwitz grow cruder, the universality of the German Jews extends, but this exacerbates their distance from Artie and from the reader - to the extent that Spiegelman is at once encouraging and rejecting any association with the experience of Auschwitz.

In the second chapter of the second volume, entitled Auschwitz (Time Flies) (Spiegelman 1986: 274, panel 4), Vladek recalls that one of his fellow inmates claimed to be a German solider, rather than a Jew - and in one panel, is drawn as a German cat in Auschwitz garb. In every other panel, however, including the one where a guard stamps on his neck and kills him, he is drawn as a mouse. This would suggest that the Jew/mouse metaphor is not one based on racial or cultural modifiers, but on the criterion of victimisation; if it does not matter that one inmate 


\section{Liam Kruger}

at Auschwitz has medals from the Kaizer, then it does not matter if another is a Jew. Either way, they are externally identified as Jews, and as victims - and therefore mice. True, the theriomorphic metaphor still holds for the German cats, Polish pigs, American dogs, Swedish moose and French frogs - and there are ethical problems with having these particularised, intrinsically less sympathetic depictions defined by purely racial or cultural criteria. This is perhaps best seen in the third chapter of Maus II, when Vladek encounters a Frenchman in Dachau. There is no reason for a French prisoner of war to be designed to be less relatable than a Jewish one, and yet it is almost impossible to look past the frog 'mask'; non-mouse characters seem less than human under the animal metaphor. It is possible, however, that Spiegelman gestures towards a breaking down of this metaphor with the increasing trend towards universalisation of the 'mouse' designation, allowing it to stand in for 'victim' rather than 'Jew', which begins to partially deal with that concern.

By destabilising the novel's central visual metaphor, and thus at least partially disrupting the process of racial or cultural specification that the metaphor runs on, Spiegelman allows for a more involved reading of the victim's experience than might otherwise be the case - involved, but nonetheless disrupted, and frequently. It is interesting to note that while Spiegelman communicates the wider trauma of the Holocaust in an iconic visual 'diction', the far more personal trauma of his mother's suicide, as narrated in the comic-within-the-comic Prisoner on the hell planet: a case history is communicated in a stylised, vaguely self-indulgent German Expressionist mode that interrupts Maus' 'pagination, style, and tone' (Chute 2006: 207) as well as the animal metaphor. We are faced instead with sketchy, moreover particularised depictions of people - which is jarring, after a hundred-odd pages of unobtrusive cartoon mice. Where the trauma of the Holocaust is made to be universal, Spiegelman sets up the trauma of Anja's death to be entirely particularised; the reader is not permitted to relate to Hell planet's gaunt, weepy narrator. Even with the comic's vaguely self-deprecating conclusion (an off-panel voice responding to Art's diatribe with 'Pipe down, mac! Some of us are trying to sleep!' [Spiegelman 1991: 105, panel 9]) and Artie's distancing himself from the comic on the return to the 'present' narrative in Maus ('I drew this story years ago ... I never thought Vladek would see it' [Spiegelman 1986: 105, panels 7-8]), Spiegelman keeps the reader at arm's length. He deploys the metatextual gesture elsewhere to point towards the problems inherent in his animal metaphor, thereby implicitly anticipating critiques of it. Similarly, here he utilises the comic-within-a-comic to simultaneously acknowledge the problem of depicting or communicating putatively inaccessible emotion or trauma, while implicitly increasing the sense of 'reality' or 'accessibility' in Maus in relation to the crude pictorialism of Prisoner on the hell planet: in the latter case, the gesture does something to dispel the problem, less so in the former. A similar (if subtler) tactic is employed in the second chapter of Volume II; Spiegelman metatextually 
voices his anxieties about the composition of Maus through another 'Art' figure in the novel's usual iconic style, but with Art as a human wearing a shaded 'Maus' mask, his human stubble visible around his jawline (Spiegelman 1991: 37, panel 1). McCloud's dictum on the technique is 'amplification through simplification'; the rule works both ways. By adding details - comparatively jarring details - to the basic 'mouse' representation, which varies very little from character to character, our process of projection is interrupted. The 'mouse face' which the reader has come to associate with the most sympathetic characters in the narrative is reduced now to a hatched mask strung to a stubbly, messy-haired artist; the particular level of detail defers the reader's identification. Spiegelman's anxieties are made entirely his own, and the reader's unconscious empathy, solicited elsewhere in the text, is interrupted here by the relative specificity of the depiction. These two instances are the exception to the novel's rule, however; for the most part, Spiegelman appears to push for a universalising style, which at once picks at the seams of his animal metaphor and allows for far greater empathy on the reader's part. We are encouraged to substitute, to some degree, the endless blank faces with our own.

So much for faces. Now to panels - we will bring the two together shortly.

Spiegelman's interest lies less with faces and panels as such, and more with the pages that they appear in - noting in his Complete Maus (1994): 'The page is the essential unit of information ... I've considered the stylistic surface [of the page] a problem to solve.'

Critical, then, is not only the 'deliberate sequence' in which panels run, but the overall effect of having these panels laid out on a page, which generates a visual effect separate from that of their narrative sequence. This narrative sequence remains important, however the comic book panel implicitly argues for the existence of a single, discrete, nondivisible instance of time, held within the borders of the panel (a time frame, of sorts). The act of placing a particular piece of dialogue or narration in conjunction with a pictorial representation within the confines of a comic book panel functions to designate that as a single experiential 'moment'. The comic book's form necessarily undermines its ability to accurately represent a diachronic experience of reality - that is, an experience of reality which gradually changes over time. Comic books are mostly synchronic; they represent specific moments in time, and their juxtaposition represents either the progression from one discrete moment to the next (as in the photographic snapshot with which the comic book panel has some level of intertextuality) or the continuous presence of various discrete moments collected within the 'frame' of a single page. The comic book page argues, then, for the continuous presence of the past, or the imminent presence of the future. Graphic narrative represents time spatially in discrete panels; it is only when these panels are placed and read in sequence that the narrative becomes intelligible. Roland Barthes 


\section{Liam Kruger}

(1972: 182-183, emphasis in the original) made a similar point in describing Michel Butor's (non-graphic) novel, Mobile:

It is by tying fragments of events together that meaning is generated, it is by tirelessly transforming these events into functions that the structure is erected: the writer (poet, novelist, chronicler) sees the meaning of the inert units in front of him only by relating them.

The sequence of narrative progression between panels set in the same time period is not, on the whole, interesting; finding Artie and his wife Françoise in the Catskill Mountains discussing Auschwitz in their car in one panel, and doing the same thing, at the same time and in the same place in the next, does not do anything that a comic book would not do anyway. It is when Spiegelman uses that same form to shift through time without appearing to shift through time - in having a discussion in the Catskill Mountains occupy the same space as Vladek's internment at Auschwitz - that the novel 'refuses telos and closure even as it narrativizes history' (Chute 2006: 202). When Vladek talks about getting his prison tattoo (Spiegelman 1991: 20 , panels 5-6), a panel is shown with a line of adumbrated mouse figures waiting to be tattooed; this panel is intersected by Vladek in the 'present,' displaying his tattoo and standing in the same pose as the inmates. Vladek is still very much 'in' that moment - he occupies the same space, and in the comic book space means time. Moreover, he does not leave that moment; the eye moves on to the next page, but Vladek as an old man remains embedded in that scene 30 years prior. The past sticks to the present. True, Spiegelman argues for a reading of comics that renders the page as atomic unit - and yet Maus is printed on both recto and verso, such that panels on one page are unavoidably juxtaposed with panels on the page opposite, and the entire double-page spread is taken in as a single system. This might not gel perfectly with Spiegelman's more fine-detail panel work. The double-page spread does not allow for the sort of interplay between panels that Spiegelman employs, for instance, in the first volume when Artie's recumbent form stretches across two panels (Spiegelman 1986: 47, panels 1-2) - his legs on the German frontier in 1939, his torso in Rego Park in the late 1970s - or in the second, when Artie's cigarette smoke is conflated with that from a crematorium chimney (Spiegelman 1991: 69, panels 6-9), either of which set up fairly complex relationships between the past and present that are not, I think, merely visual puns. Rather, taking seriously Entman's (1993: 52) definition of framing as ' $[t]$ o select some aspects of a perceived reality and make them more salient in a communicating text, in such a way as to promote a particular problem definition, causal interpretation, moral evaluation, and/or treatment recommendation', then by placing these chronologically or geographically discrete instances within the same frame or panel, Spiegelman is insisting upon a causal or thematic relationship between these instances that goes beyond mere juxtaposition. Grim as the notion 
is, the smoking Artie is, after all, a product of the man who is himself a product, or survivor, of those smoking towers. Spiegelman appears, by his framing, to be asserting that uncomfortable, historical truth. The double-page spread achieves a similar apprehension of the various narrative streams as consisting of an historical unity, but by means of a different tactic - the fostering of a greater awareness on the reader's part of the comic book as artifact.

There are at least two ways in which Spiegelman distorts history - by perforation, that is his fine-detail use of the spatial panel structure to link or separate images and text that would be untethered in a purely diachronic temporal form, and by the artifactual nature of Maus as a comic book. Consider; if we read almost any contemporary novel that is not engaged in playing visual games (ruling out, for instance, Jonathan Safran Foer's Extremely loud \& incredibly close) but is presented to us as text, the coincidence of any set of words on a page occurs purely as a result of the sequence of words written by the author and the typeface selected by the publisher. There is no juxtaposition here, and very little awareness of the physicality of the text-a physicality that continues to grow abstract as we grow more accustomed to electronic formats. This is not the case for graphic novels - in part, perhaps, because of the relative newness of the form; for many critics the appearance of a comic book on their shelves is novelty enough to bring to bear the physicality of the thing as artifact. ${ }^{1}$ Spiegelman encourages this process; in the single-volume editions by Penguin, the back cover is designed to lay the product's barcode over Vladek's Auschwitz uniform, introducing the novel's metaphor and primary concern before it has even been opened - or purchased. Several pages in the novel lack page numbers - the Prisoner on the hell planet digression, a page towards the end of the second volume where an endless pile of photographs of Artie's deceased family bleeds over the panels and off the page (Spiegelman 1991: 109, see overleaf), and perhaps most tellingly on the novel's final page, which renders a number of conclusions but does not quite end - reinforcing Chute's notion of the text refuting a teleological reading of its contents. Spiegelman himself seems to argue for a reading of the comic book as artifact in The complete Maus (1994) when he observes that the pages from Prisoner on the hell planet are set against a black background, forming a 'funereal border' visible as a thick black line when the book is closed. We can compare the Hell planet interruption to novelistic ekphrasis - a prolonged description, or depiction, of another embedded or 'framed' within the primary artwork - as time appears to pause while Artie displays his older comic to the reader's eye. When we take the novel as artifact, we can attempt to perceive the entire thing as occurring at the same instant the first panel occupying the same semantic space as the last. As a result, linear time is disrupted - a conclusion that Artie the mouse-artist rails against in his continued attempt to marshal his father's experience into a unified, sensible narrative, which is impossible. As Vladek says, 'in Auschwitz we didn't wear watches' (Spiegelman 


\section{Liam Kruger}

1991: 168, panel 6). The spatial form, as opposed to the temporal, 'moves toward an organic conception of life, a life in which events are not so much discernible points on a line as they are random (and often simultaneous) occurrences on a seamless web of experience' (Mickelsen 1981: 77).

Of course, the web of experience is not seamless - it is cut up into panels. From this we can only conclude that Spiegelman is operating somewhere between the two conceptions; the comic book relies more heavily on the spatial than the novel, but appeals to the temporal in a way that sculpture generally does not. A coherent narrative still needs to be told, hence the need for temporality, but the comic book form allows for a spatiality that juxtaposes, and at times fuses, disparate instants of time - consider, for instance, the oft-cited panel in Volume II where the feet of four hanged girls from Auschwitz are visible in the Catskill Mountains as Vladek speaks about their deaths. This is placed in the same panel - the same 'instant', despite the fact that Vladek's narration and the dead girls are miles and years apart. This argues for the continual presence of the past - to quote Gérard Genette (1966, see also Daghistany 1981: 204): 'Lost time is ... time in a pure state, that is, in fact, by the fusion of an instant of the present with an instant of the past, the contrary of time that flows; the extra-temporal, eternity.'

Note, too, that the move towards reconstituting time into an extra-temporal eternity is not the only trick of this type that comics can play with time, even though it is the visual move that Spiegelman makes most frequently in Maus. In the page directly following the unnumbered 'bleed' of photographs of Artie's deceased family members, Vladek is shown slumped on the couch with the photographs at his feet, his body divided into four separate panels - the effect being that Vladek's face, hands and feet each occupy discrete spatial 'moments', reconstructed by Artie on the comic book page but nonetheless separate. One is reminded of the end of the previous chapter, where Vladek remarks: 'All such things of the war, I tried to put out of my mind once and for all.... Until you rebuild me all this from your questions' (Spiegelman 1991: 98, panel 5).

The effect of these two elements in Spiegelman's graphic memoir is clear; by deconstructing the animal metaphor he argues for a universalised view of Auschwitz as a tragedy, not solely because Jews were killed by Germans, but because people were killed by people - a tragedy from which the reader is necessarily removed, but hopefully solely from distance of experience, not due to any personal particularities. We are invited, and indeed compelled, to project onto the gaunt faces of the victims and at the same time prevented by the exacerbated distance of their crude depiction. And of course this is Spiegelman's memoir of his father, so necessarily the extent to which the reader can project onto any given character is curtailed. But because the comic book not only narrativises Vladek's account but also Artie's attempt at narrativising the account, we find ourselves vacillating between living vicariously 
through the semi-fictional Vladek ${ }^{2}$ and recoiling from being entertained by a true-life account of Auschwitz. By deconstructing the sequence of narrative time, Spiegelman argues for an extra-temporal conception of Vladek's tragedy, such that the issue of it having occurred in an arguably remote past becomes a non-issue; the past is not past. Adorno's (1981: 34) over-quoted charge, that 'to write poetry after Auschwitz is barbaric', is not applicable here because the idea of 'after Auschwitz' is unintelligible. Faces that look a little like ours, but not quite, and time that does not run right: that is what comics can do better than prose, or poetry. Spiegelman does not offer closure; the last page 'just keeps ending', he informs us in The complete Maus, with three conclusions offered in six panels, all of them overlapped by Vladek Spiegelman's grave. This is conclusive, yes, but jars with the narrative we had been investing in, the narrative of Vladek's survival, and is itself jarred by the fact of the book in one's hands, which resurrects Vladek. As a sequential collection of faces and panels, the comic book form is one that is set up to simultaneously generate and disrupt procedures of empathy and narrativisation, soliciting the reader's understanding and demonstrating exactly where it falls short. This is not all that comics, or even graphic memoirs, can do - but it is something that the genre seems capable of doing better than any other.

\section{Notes}

1 An aside here - if we concede that the comic book is in fact a new form, one whose language is still being written ('language' in the way that the novel's language tells us that the green light in The Great Gatsby is to be taken as a metaphor and that pagination is not important, or that film's language tells us that a couple falling away from one another in bed have just slept together) and learnt, what can we expect from avant-garde comics? What will be the vantage point from which Maus will seem as pokey, as experimental as The Golden Ass? What are the implications of an art form being at an incubative stage when the technology for mass generation and proliferation of media is available?

2 Semi-fictional in that the words are real, but the drawing Spiegelman is showing us is completely made up.

\section{References}

Adorno, T. 1981. Cultural criticism and society. In Prisms, trans. S. Weber. Cambridge: MIT Press.

Barthes, R. 1972. Literature and discontinuity. In Critical essays, trans. R. Howard. Evanston: North Western University Press.

Chaney, M. 2011. Animal subjects of the graphic novel. College Literature 38(3): 130-139.

Chute, H. 2006. The shadow of a past time: history and graphic representation in 'Maus'. Twentieth Century Literature 52(2): 202-220.

Entman, R.M. 1993. Framing: towards clarification of a fractured paradigm. Journal of Communication 43(4): 52-70. 


\section{Liam Kruger}

Ewert, J. 2000. Reading visual narrative: Art Spiegelman's 'Maus'. Narrative 8(1): 57-78.

McCloud, S. 1993. Understanding comics: the invisible art. Northampton: Kitchen Sink Press.

Genette, G. 1966. Proust palimpseste. In Figure I. Paris: Seuil.

Mickelsen, D. 1981. Types of spatial structure. In Spatial form in narrative, ed. A. Daghistany and J. Smitten. Ithaca: Cornell University Press.

Spiegelman, A. 1991. Maus I: and here my troubles began. New York: Pantheon.

Spiegelman, A. 1994. Little Orphan Annie's eyeballs in The Complete Maus. New York: Voyager.

Spiegelman, A. 1994. Looney Tunes, Zionism and the Jewish Question in The Complete Maus. New York: Voyager.

Spiegelman, A. 1994. The complete Maus. New York: Voyager.

Spiegelman, A. 1986. Maus II: my father bleeds history. New York: Pantheon. 